\title{
Both insulin sensitivity and insulin clearance in children and young adults with Type I (insulin-dependent) diabetes vary with growth hormone concentrations and with age
}

\author{
C. L. Acerini, T. D. Cheetham, J. A. Edge, D. B. Dunger \\ Department of Paediatrics, University of Oxford, John Radcliffe Hospital, Oxford
}

\section{Abstract}

Aims/hypothesis. We measured insulin clearance rates in children and young adults with Type I (insulin-dependent) diabetes mellitus to establish their relation with insulin sensitivity and with factors such as growth hormone secretion and body mass index.

Methods. We studied 46 subjects [mean (range) age 14.4 (9.8-24.6) years), body mass index 21.1 (15.829.6) $\left.\mathrm{Kgm}^{2}\right]$ using an overnight (1800-0800 hours) variable rate insulin infusion euglycaemic clamp protocol $(5 \mathrm{mmol} / \mathrm{l})$. Plasma free insulin concentrations during steady-state euglycaemia were used as an index of insulin sensitivity and insulin clearance determined as a ratio of insulin infusion rate to plasma free insulin.

Results. During steady-state euglycaemia (05000730 hours), insulin sensitivity [mean (SEM) plasma insulin $0.020(0.002) \mathrm{mU} / \mathrm{l}]$ and insulin clearance rates [19.1 (1.8) $\left.\mathrm{ml} \cdot \mathrm{kg}^{-1} \cdot \mathrm{min}\right]$ varied with age non-linearly and in a reciprocal fashion to each other (cubic regression $F=4.09, p=0.01 ; F=3.55, p=0.02$, respec- tively). Insulin sensitivity was negatively related to BMI $(r=-0.37, p=0.011)$ and mean overnight growth hormone concentrations $(r=-0.40$, $p=0.007)$. Insulin clearance was only related to growth hormone concentrations $(r=-0.37$, $p=0.014)$. These relations were still evident after stepwise multiple regression analysis (potential determinants: $\mathrm{C}$ peptide, sex, age, puberty stage, $\mathrm{HbA}_{1 \mathrm{c}}$, duration of diabetes): insulin sensitivity $r=0.55, p<0.001$; insulin clearance $r=0.37, p<0.02$. Conclusions/interpretation. Insulin clearance rates vary with age in young subjects with Type I diabetes and are highest during mid-adolescence when insulin sensitivity is at its lowest. Both insulin sensitivity and insulin clearance are related to circulating growth hormone concentrations. [Diabetologia (2000) 43: 61-68]

Keywords Type I diabetes, insulin sensitivity, insulin clearance, growth hormone, age, body mass index, children and adolescents.
Reductions in insulin sensitivity occur during normal pubertal development and are known to be greater in those with Type I (insulin dependent) diabetes mellitus [1,2]. These changes have been attributed to alterations in insulin action in peripheral tissues [3], and are thought to occur secondary to puberty-associated increases in growth hormone $(\mathrm{GH})$ secretion [4] which are exaggerated in Type I diabetes [5]. Nev-

Corresponding author: Dr C. Acerini, Department of Paediatrics, Addenbrooke's Hospital, Cambridge. CB2 2QQ, UK Abbreviations: MCR-I, Metabolic clearance rate insulin; GH, growth hormone. ertheless, the mechanisms that regulate insulin sensitivity are not clearly defined and could involve factors that alter insulin action at the level of the insulin receptor, as well as changes in post receptor signalling events.

There are few data regarding insulin clearance rates in patients with Type I diabetes and those that have been reported refer to decreased [6], increased [7] or unchanged [8] clearance when compared with healthy control subjects. In healthy adult subjects there is some evidence that insulin clearance rates differ between the sexes and decline with age $[9,10]$, as well as being influenced by factors such as the de- 
gree of obesity [11] and circulating GH concentrations [12]. Furthermore, in adolescents with Type I diabetes changes in insulin clearance rates during the night have been implicated in the aetiology of the dawn phenomenon $[13,14]$

Insulin clearance rates during puberty and early adult life have not been defined in patients with Type I diabetes. The aims of our study were to determine insulin clearance rates in a large cohort of children and adolescents with Type I diabetes using euglycaemic clamp techniques to establish relations with measures of insulin sensitivity and with factors such as obesity, puberty stage and GH secretion.

\section{Subjects and methods}

Subjects. Children and young adults ( $n=46,15$ males) with Type I diabetes took part in the study. All were in good health with normal renal, hepatic and thyroid function and were on combinations of intermediate (isophane) and short acting (soluble) insulin given two to four times a day. Haemaglobin $A_{1 c}$ and C-peptide concentrations (when blood glucose concentrations were greater than $7.0 \mathrm{mmol} / \mathrm{l})$ were determined at the time of recruitment to the study. Patient characteristics are summarised in Table 1. The Central Oxford Research Ethics Committee approved the study protocol and informed consent was obtained from subjects and, where appropriate, from their parents. All studies were carried out at the John Radcliffe Hospital in Oxford.

Research design. Before each study all intermediate insulin was withdrawn for at least $36 \mathrm{~h}$. Blood glucose concentrations were controlled by four daily injections of soluble insulin; the last being given between 1200 and 1300 hours on the day of the study. Subjects were admitted to the ward at 1700 hours and two intravenous cannulae inserted, one into a distal forearm vein for blood sampling and the other into an antecubital fossa vein for infiltrating fluids. A standardised carbohydrate meal was given between 1730 and 1800 hours, and subjects then fasted until at least 0800 hours the next day. Baseline blood samples were taken at 1730 hours before commencing a variable rate insulin infusion that was given continuously over-

Table 1. Subject characteristics

\begin{tabular}{|c|c|c|c|c|c|}
\hline & \multicolumn{5}{|c|}{ Puberty stage } \\
\hline & I & II & III & IV & $\mathrm{V}$ \\
\hline Total (n) & 4 & 6 & 4 & 8 & 24 \\
\hline \multirow[t]{2}{*}{ Sex $(n)$ male/female } & $2 / 2$ & $4 / 2$ & $1 / 3$ & $0 / 8$ & $8 / 16$ \\
\hline & \multicolumn{5}{|c|}{$\begin{array}{l}\text { Median for whole group } \\
\text { (range) }\end{array}$} \\
\hline Age (years) & \multicolumn{5}{|c|}{$14.4(9.8-24.6)$} \\
\hline $\begin{array}{l}\text { Duration diabetes } \\
\text { (years) }\end{array}$ & \multicolumn{5}{|c|}{$6.3(1.5-13.8)$} \\
\hline C peptide (pmol/l) & \multicolumn{5}{|c|}{$0.06(0.01-0.12)$} \\
\hline $\begin{array}{l}\text { Insulin dose } \\
\left(\mathrm{U} \cdot \mathrm{kg}^{-1} \cdot \mathrm{day}^{-1}\right)\end{array}$ & \multicolumn{5}{|c|}{$0.96(0.57-1.69)$} \\
\hline $\mathrm{HbA}_{1 \mathrm{c}}(\%)$ & \multicolumn{5}{|c|}{$11.0(7.0-17.0)$} \\
\hline BMI $\left(\mathrm{kg} / \mathrm{m}^{2}\right)$ & \multicolumn{5}{|c|}{$21.1(15.8-29.6)$} \\
\hline
\end{tabular}

night until 0800 hours the next morning. The rate of insulin infusion was adjusted according to $15 \mathrm{~min}$ blood glucose measurements to achieve and maintain a blood glucose concentration of around $5 \mathrm{mmol} / \mathrm{l}$ [15]. No glucose was given during this period.

Throughout the entire study period (1730 to 0800 hours) blood samples were taken at regular intervals for the measurement of GH (15 min) and plasma free insulin (30 min). Blood non-esterified fatty acids (NEFAs) were measured during the period of steady-state euglycaemia $(15 \mathrm{~min})$. Blood samples were taken from a continuously heparinised cannula inserted into a distal forearm vein, which was covered in a heated blanket to arterialise venous blood [16]. Blood sample volumes varied between $0.1-5.0 \mathrm{ml}$, depending on requirements and approximately $225 \mathrm{mls}$ of blood were obtained from each subject during each study, which was replaced with an equivalent volume of normal saline. Subjects remained supine throughout and had similar sleep patterns.

Assay methods. Free insulin concentrations were determined by first mixing $1.0 \mathrm{ml}$ of whole blood into a $25 \%$ solution of polyethylene glycol 6000 (Merck, Poole, Dorset, UK) to remove insulin antibodies [17]. This was then centrifuged at $3000 \mathrm{rev} / \mathrm{min}$ in a Beckman Model J-6B Centrifuge and the supernatant separated and stored at $-20^{\circ} \mathrm{C}$ until assayed with a double antibody radioimmunoassay (Diagnostic Systems Laboratories, Webster, Texas, USA.). The intra-assay coefficients of variations were $8.2 \%, 4.8 \%$ and $6.3 \%$ at 29,106 and 328 $\mathrm{pmol} / \mathrm{l}$, respectively. The inter-assay coefficients of variation were $11.2 \%, 9.2 \%$ and $4.7 \%$ at 30,97 and $318 \mathrm{pmol} / 1$, respectively.

Samples for GH analysis were initially kept at room temperature until completion of each study, before being spun and separated for storage at $-20^{\circ} \mathrm{C}$. Plasma $\mathrm{GH}$ was then measured by immunoradiometeric assay (NETRIA, St. Bartholomew's Hospital, London, UK) using an international reference standard 80/505. All samples from each subject were analysed in the same batch. The intra-assay coefficients of variation at growth hormone concentrations of $2.9,14.3$ and $69.4 \mathrm{mU} / 1$ were $8.0,2.0$ and $3.4 \%$, respectively, while inter-assay coefficients of variation at $\mathrm{GH}$ concentrations of $3.5,15.2$ and $77.4 \mathrm{mU} / \mathrm{l}$ were $9.4,7.7$ and $10.5 \%$ respectively. Assay sensitivity was quoted at $0.2 \mathrm{mU} / 1$.

Plasma samples for NEFAs were stored at $-20{ }^{\circ} \mathrm{C}$ until assay with a Wako NEFA C kit (Alpha Laboratories, Eastleigh, Hants, UK). The assay detection limit was $10 \mu \mathrm{mol} / \mathrm{l}$ and inter-assay and intra-assay coefficients of variation were $2.5 \%$ at 500 and $1000 \mu \mathrm{mol} / \mathrm{l}$.

Glycated haemoglobin levels $\left(\mathrm{HbA}_{1 \mathrm{c}}\right)$ were measured by high pressure liquid chromatography (HPLC) (Diamat, BioRad Laboratories, Hemel Hempstead, UK). The intra-assay coefficients of variation were 1.9 and $2.2 \%$ at $\mathrm{HbA}_{1 \mathrm{c}}$ values of 6.9 and $11.5 \%$, respectively. The inter-assay coefficients of variation were 2.7 and $2.3 \%$ at $\mathrm{HbA}_{1 \mathrm{c}}$ values of 7.0 and $11.6 \%$, respectively. Normal range $\mathrm{HbA}_{1 \mathrm{c}}$ values were 4.3 to $6.1 \%$. Concentrations of $\mathrm{C}$ peptide were determined by a double antibody radioimmunoassay (Diagnostic Products, Euro/ DPC, Llanberis, Caernarfon, Wales). Intra-assay coefficients of variation were 3.4 and $3.0 \%$ at $\mathrm{C}$ peptide concentrations of 294 and $2614 \mathrm{pmol} / \mathrm{l}$, respectively and inter-assay coefficients of variation were 10.0 and $1.9 \%$ at $\mathrm{C}$ peptide concentrations of 297 and $2929 \mathrm{pmol} / \mathrm{l}$, respectively. Whole blood glucose was measured at the bedside using a glucose oxidase method (YSI analyser, Clandon Scientific, Farnbourgh, Hants, UK). 


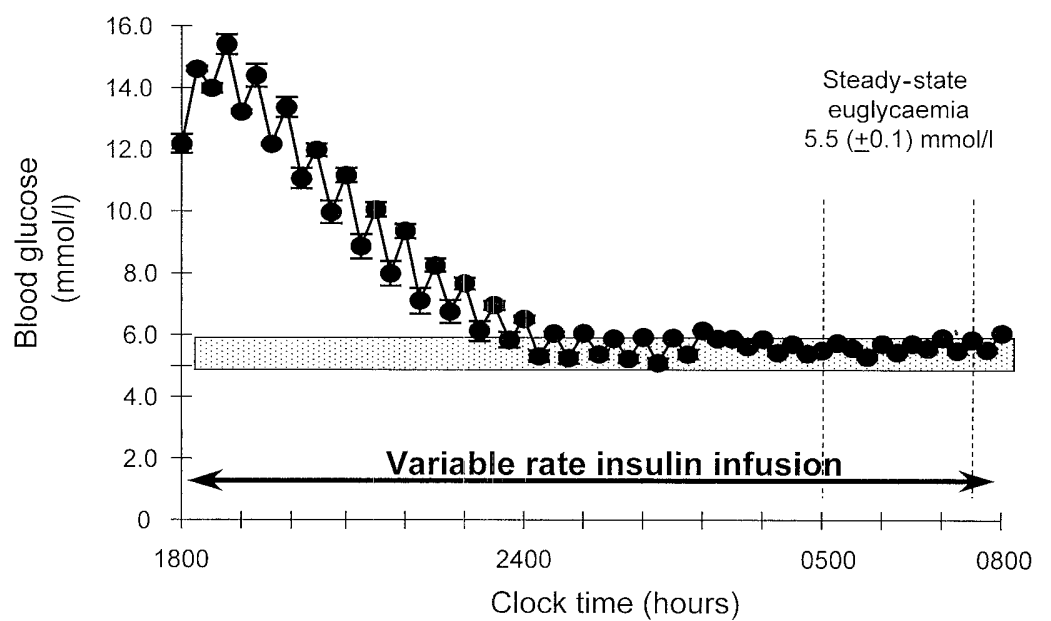

Fig. 1. Means \pm SEM blood glucose concentrations for all subjects. $\square$ represents blood glucose clamp target. The period of steady-state euglycaemia between 0500 to 0730 hours is shown

Data analysis. A period of steady-state euglycaemia was deemed to be achieved when blood glucose concentrations showed no statistically significant change with time within and between subjects as determined by analysis of variance (ANOVA) for repeated measures. As a group this was achieved between 0500 and 0730 hours.

Plasma free insulin concentrations for the period of steadystate euglycaemia were used as an index of insulin sensitivity. Changes in insulin concentrations required to maintain euglycaemia during this fasting period in subjects with Type I diabetes have been shown to be partly related to changes in peripheral insulin-stimulated glucose metabolism [18-20].

Metabolic clearance rates for plasma insulin (MCR-I) were determined for the period of steady-state euglycaemia as a ratio of insulin infusion rate to plasma free insulin concentration [21]:

$\operatorname{MCR}-\mathrm{I}\left(\mathrm{ml} \cdot \mathrm{kg}^{-1} \cdot \min ^{-1}\right)=\frac{\text { Insulin infusion }\left(\text { unit } \cdot \mathrm{kg}^{-1} \cdot \mathrm{min}^{-1}\right)}{\text { Plasma-free insulin }(\mathrm{mU} / \mathrm{l})}$

Statistics. All data are expressed as means \pm standard error of the mean (SEM) unless otherwise stated. Analysis of variance with repeated measures was used to determine the period of steady-state euglycaemia. The $t$ test for independent samples was used to detect differences in mean data between the sexes. Cubic regression modelling was used to examine the non-linear relation between the dependent variables, insulin sensitivity and MCR-I, and age. Simple linear regression was used in comparisons with all other independent variables. The determinants of insulin sensitivity (as reflected by plasma free insulin concentrations) and of MCR-I were examined using stepwise (forwards) multiple regression analysis. We used SPSS for MS Windows 95 (release 7.5.1 (SPSS, Chicago, Ill., USA) for all analyses. $P$ values less than 0.05 were considered to be significant.

\section{Results}

Overnight blood glucose concentrations declined steadily and concentrations approaching $5 \mathrm{mmol} / \mathrm{l}$ were achieved in most subjects by 0100 hours. During steady-state euglycaemia (0500-0730 hours), mean blood glucose concentrations for the group were $5.5 \pm 0.1 \mathrm{mmol} / \mathrm{l}$, with no significant differences between the sexes (males $=5.3 \pm 0.1 \mathrm{mmol} / 1$ vs females $=5.7 \pm 0.2 \mathrm{mmol} / \mathrm{l})($ Fig. 1$)$.

Plasma free insulin concentrations during steadystate euglycaemia were $0.020 \pm 0.002 \mathrm{mU} / \mathrm{ml}$. No significant differences in free insulin concentrations for this period were observed when compared by sex (males $=0.018 \pm 0.003 \mathrm{mU} / \mathrm{ml}$ vs females $=0.021 \pm$ $0.002 \mathrm{mU} / \mathrm{ml}$ ). A non-linear relation between plasma free insulin concentrations and age was seen, with those for steady-state euglycaemia at their lowest in the younger children and in the young adults, compared with young people in the mid-teenage years (Fig. 2a). This relation was statistically significant when examined by non-linear cubic regression modelling $(F=4.09, p=0.01)$.

Mean insulin infusion rates and calculated mean MCR-Is during steady-state euglycaemia were $0.29 \pm 0.02$ units $\cdot \mathrm{kg}^{-1} \cdot \mathrm{min}^{-1}$ and $19.1 \pm 1.8 \mathrm{ml}$. $\mathrm{kg}^{-1} \cdot \mathrm{min}^{-1}$, respectively. The MCR-Is were similar in male $\left(18.7 \pm 2.5 \mathrm{ml} \cdot \mathrm{kg}^{-1} \cdot \mathrm{min}^{-1}\right)$ and female subjects $\left(19.3 \pm 2.4 \mathrm{ml} \cdot \mathrm{kg}^{-1} \cdot \mathrm{min}^{-1}\right)$. There was a significant non-linear relation between MCR-Is and age, although this was the reciprocal of that seen between plasma free insulin and age (cubic regression $F=3.55, p=0.02)$ (Fig. 2b). Predictably MCR-I's for steady-state euglycaemia were significantly correlated to plasma free insulin concentrations $(r=0.65$, $p=<0.001)$.

Mean plasma $\mathrm{GH}$ concentrations for the overnight period between 2000 to 0800 hours were determined for each subject and ranged from a maximum value of $59.9 \mathrm{mU} / \mathrm{l}$ to a minimum of $6.2 \mathrm{mU} / \mathrm{l}$ (mean $21.8 \pm 1.7 \mathrm{mU} / \mathrm{l})$. No differences in mean values were seen between male $(22.4 \pm 3.8 \mathrm{mU} / \mathrm{l})$ and female subjects $(21.5 \pm 1.9 \mathrm{mU} / \mathrm{l})$. Mean plasma NEFAs during steady-state euglycaemia ranged from $347 \mu \mathrm{mol} / 1$ to $1467 \mu \mathrm{mol} / \mathrm{l}$ (mean $808 \pm 53 \mu \mathrm{mol} / \mathrm{l}$ ) with no differences seen between the sexes (mean males $766 \pm 92 \mu \mathrm{mol} / \mathrm{l}$ vs females $830 \pm 65 \mu \mathrm{mol} / \mathrm{l})$. 


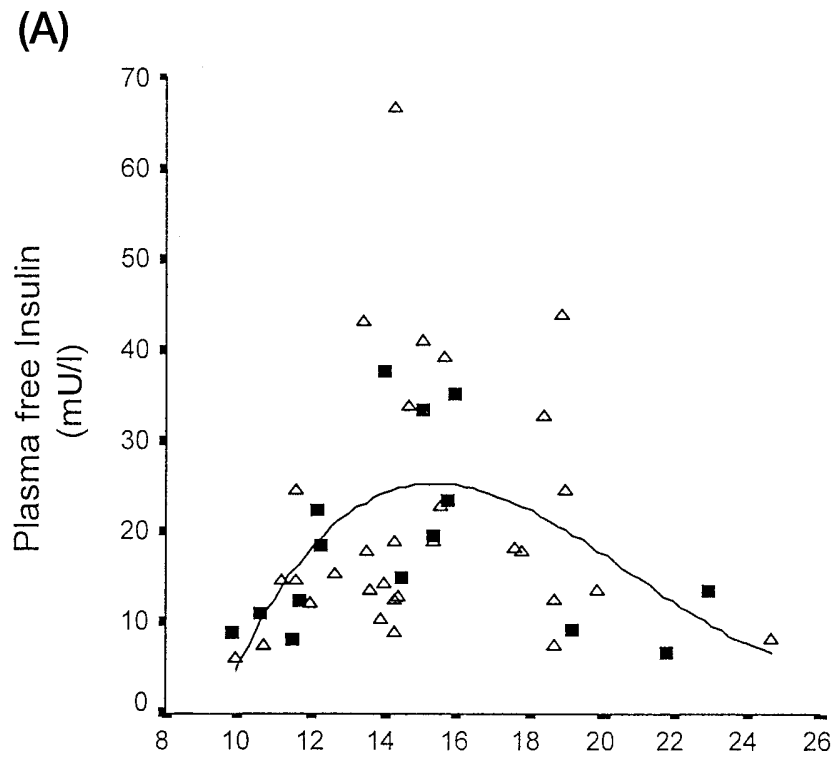

(B)

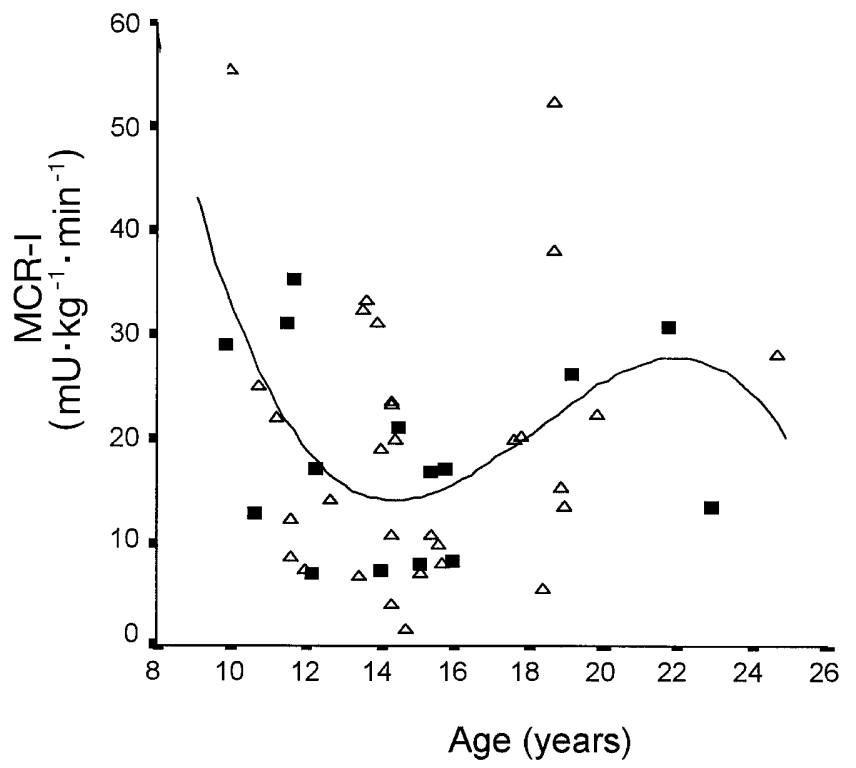

Fig. $2 \mathbf{A}$, B. The relation between age and (A) insulin sensitivity (represented by steady-state euglycaemia plasma free insulin concentrations), $(F=4.09, p=0.01)$ and $(\mathbf{B})$ steady-state euglycaemia metabolic clearance rate - insulin (MCR-I) $(F=3.55, p=0.02)$ Individual mean concentrations/rates for male $(\square)$ and female $(\Delta)$ subjects are shown

Insulin sensitivity, as determined by steady-state euglycaemia mean plasma free insulin concentrations, showed a significant linear relation to BMI $(r=-0.37, p=0.011$, Fig. 3), mean overnight GH concentrations ( $r=-0.40, p=0.007$, Fig. 4 a) and puberty stage $(p=0.004)$. In contrast, MCR-Is were only reciprocally related to overnight $\mathrm{GH} \quad(r=-0.37$, $p=0.014$, Fig. 4 b). These relations, with the exception of that between insulin sensitivity and puberty stage, were still evident when examined by stepwise

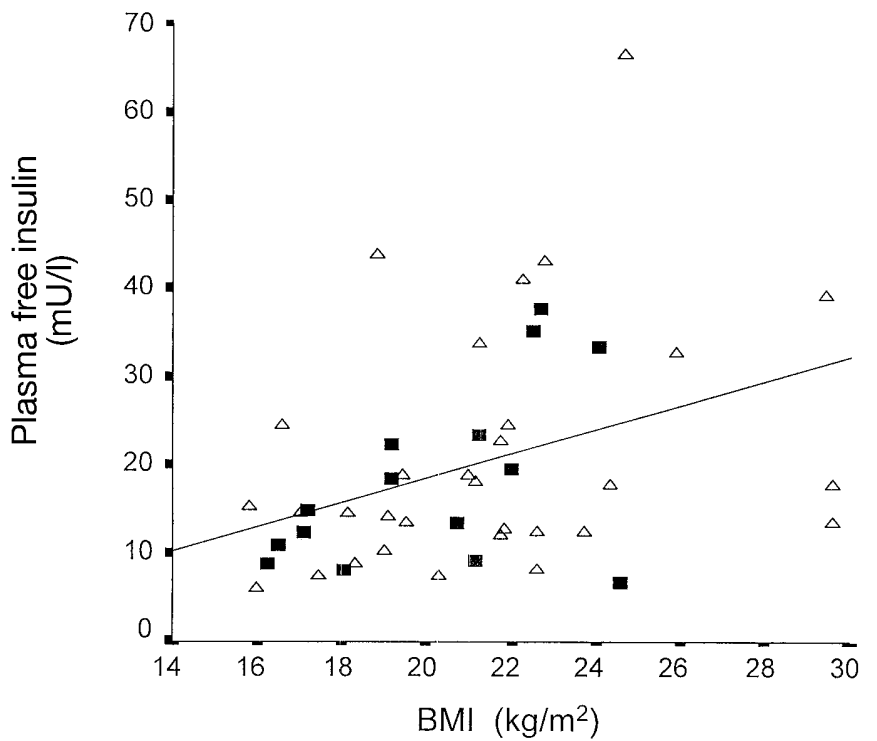

Fig. 3. The relation between insulin sensitivity (represented by steady-state euglycaemia plasma free insulin concentrations) and body mass index (BMI). $r=0.37, \mathrm{y}=2.935+5.997 \mathrm{x}$, $p=0.011$. Individual mean concentrations/indexes for male (ם) and female $(\Delta)$ subjects are shown

(forward) multiple regression, in which all other variables thought to be potential determinants (including NEFAs, $\mathrm{C}$ peptide, sex, $\mathrm{HbA}_{1 \mathrm{c}}$ and duration of diabetes) were entered into the model. The results of stepwise linear multiple regression analysis are shown in Table 2.

\section{Discussion}

We used plasma free insulin concentrations during a period of steady-state euglycaemia as an index of peripheral insulin sensitivity. An association between changes in plasma insulin concentrations and insulin infusion requirements during the early morning period have been attributed to changes in insulin sensitivity and specifically to changes in insulin stimulated glucose metabolism in subjects with Type I diabetes $[19,20,22]$. We observed differences in insulin sensitivity according to age, with values at their lowest during the adolescent years (Fig. 2a). This is in keeping with previous reports that have noted reductions in insulin sensitivity coinciding with puberty in subjects with Type I diabetes $[1,2]$. Variations were also seen with age, with MCR-Is falling and reaching a nadir in the mid-teenage years, before rising again in later life (Fig. 2b). We have shown a relation between insulin clearance and age in a large cohort of children and adolescents with Type I diabetes. In adults with diabetes this relation has not been previously reported, although in healthy adults MCR-I has been variously observed as remaining unchanged [23] or declining $[9,10]$ with advancing age. In these studies 
(A)
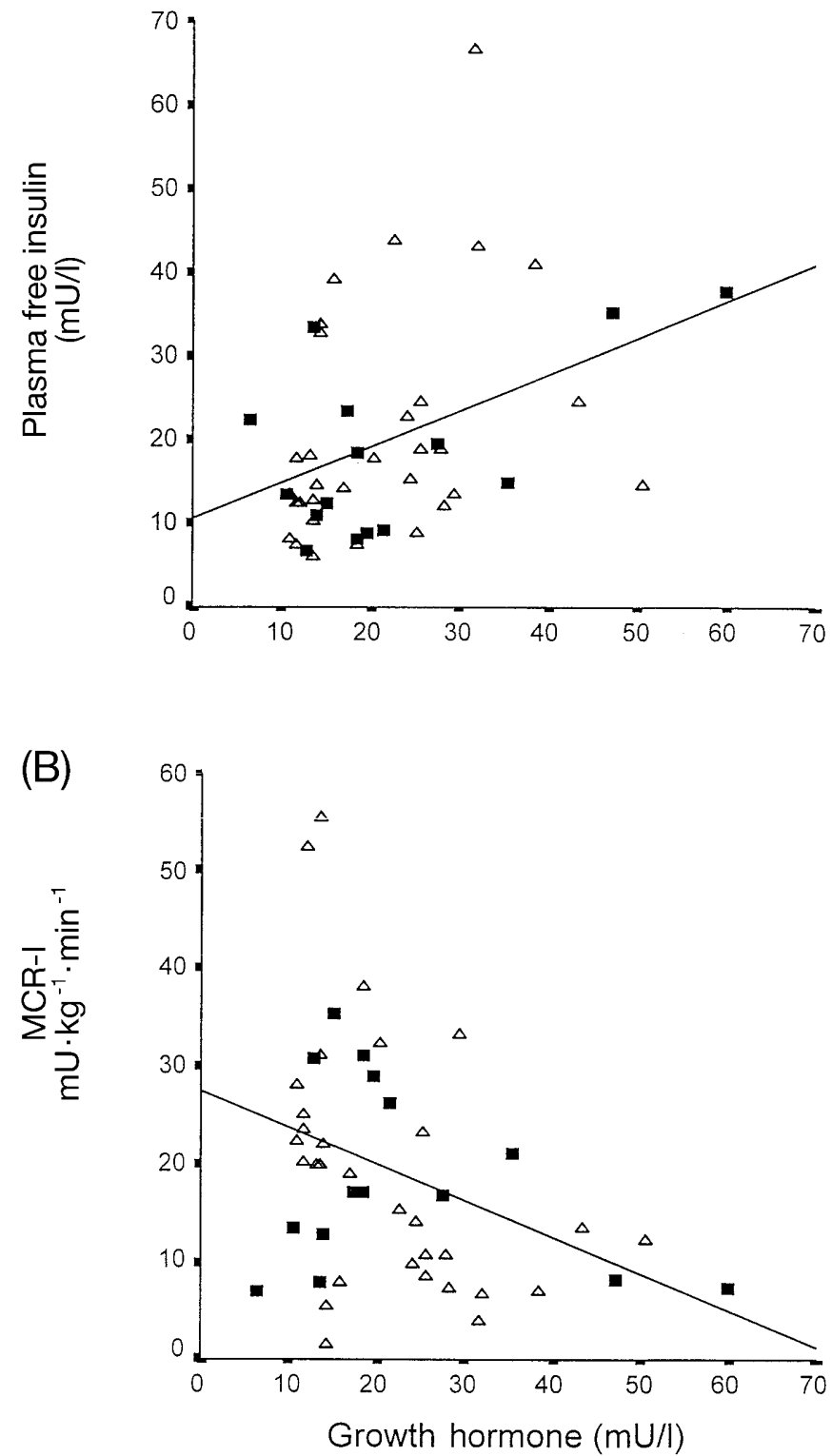

Fig.4A, B. The relation between mean overnight growth hormone concentrations and (A) insulin sensitivity (represented by steady-state euglycaemia plasma free insulin concentrations) $r=0.40, \mathrm{y}=2.935+0.439 \mathrm{x}, p=0.007$. and (B) steadystate euglycaemia metabolic clearance rate - insulin (MCR-I) $r=-0.37, \mathrm{y}=27.275-0.374 \mathrm{x}, p=0.014$. Individual mean concentrations/rates for male $(\square)$ and female $(\Delta)$ subjects are shown

other age-related variables such as changes in physical activity and in metabolic rate could, however, have had a role in determining insulin clearance rates [24].

We determined insulin clearance rates in subjects with Type I diabetes using a simple physiological model, using a variable rate insulin infusion, euglycaemic clamp technique. By maintaining normoglycaemia we have eliminated possible changes in insu-
Table 2. The results of stepwise linear regression analysis used to assess determinants of insulin sensitivity (plasma free insulin concentrations and metabolic clearance rate of insulin (MCR-I) during steady-state euglycaemia

\begin{tabular}{lrll}
\hline Dependent variable & Coefficient & $\begin{array}{l}\text { SE } \\
\text { coefficient }\end{array}$ & $p$ value \\
\hline Insulin sensitivity & & & \\
$\quad$ Growth hormone & 0.039 & $<0.001$ & 0.002 \\
BMI & 0.002 & $<0.001$ & 0.005 \\
Constant & -0.145 & 10.49 & \\
$r$ & 0.548 & & \\
$\quad$ Adjusted $r^{2}$ & 0.300 & & \\
MCR-I & & & \\
Growth hormone & -0.374 & 0.143 & 0.024 \\
Constant & 16.844 & 5.628 & \\
$r$ & 0.470 & & \\
$\quad$ Adjusted $r^{2}$ & 0.221 & & \\
\hline
\end{tabular}

lin clearance induced by either hyperglycaemia or hypoglycaemia [21]. Also, by infusing physiological amounts of insulin, reductions in insulin clearance brought about by insulin receptor saturation and down-regulation, as encountered with supraphysiological insulin treatment, were also avoided [25].

A positive relation between our measure of peripheral insulin sensitivity and overnight GH concentrations was observed. Similar findings have been reported in subjects with Type I diabetes, where measures of early morning insulin sensitivity were strongly related to overnight $\mathrm{GH}$ secretion [19, 26, 27, 28]. It is has been suggested that reductions in insulin sensitivity at this time are attributable to the effects of $\mathrm{GH}$ on peripheral glucose metabolism [3]. The insulin antagonistic effects induced by $\mathrm{GH}$ are thought to be principally mediated in the peripheral tissues $[29,30]$ yet the mechanisms for this effect are still ill defined. Growth hormone could be acting directly through its own receptor with interaction with insulin signalling at a post receptor level, or be acting indirectly through mobilisation of NEFAs from adipose tissue. These have suppressive effects on peripheral glucose metabolism by inhibiting peripheral glucose oxidation and glycolysis [31, 32, 33] and have been implicated in regulating hepatic glucose metabolism and mediating the actions of insulin on the liver [34, 35].

We also observed a statistically significant negative linear relation between mean overnight GH concentrations and insulin clearance rates in keeping with other reports. In dogs, exogenous GH treatment results in reductions in insulin clearance [36] and in Turner's syndrome raised insulin clearance rates were decreased to normal with GH therapy [37]. Nevertheless, our results contrast with those seen in studies of the dawn phenomenon in patients with Type I diabetes, where raised early morning insulin requirements have been linked to increases in insulin clearance. This has been attributed to surges in noc- 
turnal GH secretion [13, 14], although this has not been consistently observed [27, 38]. Methodological differences could account for the discrepancies seen between these and our studies, particularly as many used fixed insulin rates and the use of closed-loop insulin infusion devices ("Biostator device") which can introduce error in the calculation of insulin clearance rates $[39,40]$. Moreover other factors, such as differences in the age of the subjects used and the presence of higher circulating insulin antibody titres can also affect insulin clearance [41]. Insulin antibodies were not measured in our study but are unlikely to have been present in our subjects given their young age and likelihood that all had been treated with recombinant human insulin since diagnosis. A relation between BMI and insulin clearance rates has also been reported [42] but was not seen in our study. This could be explained by the lack of any extremes in BMI values in our subjects, although a recent study of patients with polycystic ovarian syndrome noted that insulin clearance rates were reduced independent of BMI [43].

Non-esterified fatty acids could be important in explaining the relations seen between insulin sensitivity and insulin clearance with both GH and BMI. A negative relation between BMI and insulin sensitivity is recognised in obese subjects with and without diabetes [44, 45, 46], and there is evidence linking increased concentrations of NEFAs to the development of insulin resistance in subjects with increased BMI [47, 48]. Small increments in BMI have also been associated with reduced insulin clearance rates and increased NEFAs in patients with glucose intolerance [42]. Experiments in rats suggests that NEFAs reduce hepatic insulin uptake and insulin degradation $[49,50]$. Furthermore, in humans NEFA's have been shown to alter hepatic insulin clearance and have been implicated in the reduced insulin sensitivity associated with Type II (non-insulin dependent) diabetes mellitus [51]. We did not see any relation between mean steady-state euglycaemia plasma NEFA concentrations with $\mathrm{GH}$, insulin sensitivity or insulin clearance, although it cannot be entirely discounted. Early morning fasting ketone and NEFA concentrations seem to be determined by plasma insulin concentrations, whereas those during the early part of the night are related to $\mathrm{GH}$ [52]. The concentrations of NEFA in our study were measured from plasma samples that were collected and stored in the presence of heparin, which is well known to cause the release of NEFAs in blood through the activation of lipoprotein lipase activity and could have interfered with our final results [53].

The relations seen in our study also raise the question as to whether insulin clearance could be another factor that regulates insulin sensitivity in patients with Type I diabetes. In vitro, after insulin receptor binding and internalisation into cells, insulin and the enzymatic processes involved in its degradation can have effects on the generation of insulin action [54, 55]. The liver is the primary site for the clearance of insulin from the circulation $[56,57]$ and in liver disease states, decreases in insulin clearance have been associated with reductions in hepatic insulin sensitivity [58]. In both non-diabetic insulin resistant patients and healthy human subjects strong relations between insulin sensitivity and insulin clearance have also been reported $[59,60]$. Although it cannot be discounted that insulin clearance could be a determinant of insulin sensitivity there are other explanations that could account for this association. For example, reductions in insulin receptor numbers at the tissues would have an affect on both insulin clearance rates and insulin action. There is some evidence that factors causing abnormalities in the post-receptor mechanisms that could be responsible for reduced insulin sensitivity could also cause reductions in insulin receptor numbers and thus reduce insulin receptor mediated clearance [61].

In conclusion, our study has shown that insulin clearance rates vary with age in young subjects with Type I diabetes and are highest during mid-adolescence when insulin sensitivity is at its lowest. Both insulin clearance and insulin sensitivity are related to circulating GH concentrations, whereas insulin sensitivity alone is correlated with BMI values. Our study highlights the complex inter-relations that exist between age, GH and BMI in the determination of insulin sensitivity in subjects with Type I diabetes.

Acknowledgements. This study was supported by grants from Pharmacia \& Upjohn, Stockholm, Sweden (C.L. Acerini and T.D. Cheetham) and from Novo-Nordisk Laboratories (J.A. Edge). We thank D. Harris, A. Watts, S. Strang and Dr E. Crowne for their assistance and support.

\section{References}

1. Amiel SA, Sherwin RS, Simonson DC, Lauritano AA, Tamborlane WV (1986) Impaired insulin action in puberty. A contributing factor to poor glycemic control in adolescents with diabetes. N Engl J Med 315: 215-219

2. Bloch CA, Clemons P, Sperling MA (1987) Puberty decreases insulin sensitivity. J Pediatr 110: 481-487

3. Amiel SA, Caprio S, Sherwin RS, Plewe G, Haymond MW Tamborlane WV (1991) Insulin resistance of puberty: a defect restricted to peripheral glucose metabolism. J Clin Endocrinol Metab 72: 277-282

4. Press M, Tamborlane WV, Sherwin RS (1984) Importance of raised growth hormone levels in mediating the metabolic derangements of diabetes. N Engl J Med 310: 810-815

5. Edge JA, Dunger DB, Matthews DR, Gilbert JP, Smith CP (1990) Increased overnight growth hormone concentrations in diabetics compared with normal adolescents. J Clin Endocrinol Metab 71: 1356-1362

6. Hachiya HL, Treves ST, Kahn CR, Sodoyez JC, SodoyzGoffaux F (1987) Altered insulin distribution and metabolism in Type I diabetics assessed by [ $\left.{ }^{123} \mathrm{I}\right]$ - insulin scanning. J Clin Endocrinol Metab 64: 801-808 
7. Waldhausl WK, Bratusch-Marrin P, Kruse V, Jensen I, Nowotny P, Vierhapper H (1985) Effect of insulin antibodies on insulin pharmacokinetics and glucose utilization in insulin-dependent diabetic patients. Diabetes 34: 166-173

8. Navalesi R, Pilo A, Ferrannini E (1978) Kinetic analysis of plasma insulin disappearance in nonketotic patients and in normal subjects. J Clin Invest 61: 197-208

9. Reaven GM, Greenfield MS, Mondon CE, Rosenthal M, Wright D, Reaven EP (1982) Does insulin removal rate from plasma decline with age? Diabetes 31: 670-673

10. Fink RI, Revers RR, Kolterman OG, Olefsky JM (1985) The metabolic clearance rate of insulin and the feedback inhibition of insulin secretion are altered with aging. Diabetes 34: $275-280$

11. Trischitta V, Brunetti A, Chiavetta A, Benzi L, Papa V, Vigneri R (1989) Defects in insulin-receptor internalization and processing in monocytes of obese subjects and obese NIDDM patients. Diabetes 38: 1579-1584

12. Schade DS, Eaton RP, Peake GT (1978) The regulation of plasma ketone body concentration by counter-regulatory hormones in man. II. Effects of growth hormone in diabetic man. Diabetes 27: 916-923

13. Arslanian S, Ohki Y, Becker DJ, Drash AL (1992) The dawn phenomenon : comparison between normal and insulin-dependent diabetic adolescents. Pediatr Res 31: 203-206

14. Boyle PJ, Avogaro A, Smith L, Shah SD, Cryer PE, Santiago JV (1992) Abscence of the Dawn Phenomenon and abnormal lipolysis in Type I (insulin dependent) diabetic patients with chronic growth hormone deficiency. Diabetologia 35: 372-379

15. Matthews DR, Edge JA, Dunger DB (1990) An unbiased glucose clamp method using a variable insulin infusion : its application in diabetic adolescents. Diabet Med 7: 246-251

16. McGuire EAH, Helderman JH, Tobin JD, Anders R, Berman M (1976) Effects of arterial versus venous sampling on analysis of glucose kinetics in man. Journal of Appl Physiol 41: 565-573

17. Collins ACG, Pickup JC (1985) Sample preparation and radioimmunoassay for circulating free and antibody bound insulin concentrations in insulin treated diabetics : a reevaluation of methods. Diabet Med 2: 456-460

18. Campbell PJ, Bolli GB, Cryer PE, Gerich JE (1985) Pathogenesis of the dawn phenomenon in patients with insulindependent diabetes mellitus. Accelerated glucose production and impaired glucose utilization due to nocturnal surges in growth hormone secretion. $\mathrm{N}$ Engl J Med 312: 1473-1479

19. Beaufrere B, Beylot M, Metz C et al. (1988) Dawn phenomenon in Type I (insulin-dependent) diabetic adolescents: influence of nocturnal growth hormone secretion. Diabetologia 31: 607-611

20. Aman J, Kroon M, Karlsson I, Jones I, Hagenas L (1996) Reduced growth hormone secretion improves insulin sensitivity in adolescent girls with Type I diabetes. Acta Paediatr 85: 31-37

21. Castillo MJ, Scheen AJ, Letiexhe MR, Lefebvre PJ (1994) How to measure insulin clearance. Diabetes Metab Rev 10: $119-150$

22. Perriello G, DeFeo P, Torlone E et al. (1991) The dawn phenomenon in Type I (insulin-dependent) diabetes mellitus: magnitude, frequency, variability, and dependency on glucose counterregulation and insulin sensitivity. Diabetologia 34: 21-28

23. Jackson RA, Blix PM, Matthews JA et al. (1982) Influence of aging on glucose homeostasis. J Clin Endocrinol Metab 55: $840-848$
24. Tuominen JA, Ebeling P, Koivisto VA (1997) Exercise increases insulin clearance in healthy man and insulin-dependent diabetes mellitus patients. Clin Physiol 17: 19-30

25. Heine RJ, Bilo HJG, Van der Meer, J Van der Veen EA (1986) Sequential infusions of glucose and insulin at prefixed rates : a simple method for assessing insulin sensitivity and insulin responsivness. Diabetes Res 3: 453-461

26. Edge JA, Matthews DR, Dunger DB (1990) The dawn phenomenon is related to overnight growth hormone release in adolescent diabetics. Clin Endocrinol (Oxf) 33: 729-737

27. Perriello G, DeFeo P, Torlone E et al. (1990) Nocturnal spikes of growth hormone secretion cause the dawn phenomenon in Type I (insulin dependent) diabetes mellitus by decreasing hepatic (and extrahepatic) sensitivity to insulin in the absence of insulin waning. Diabetologia 33: 52-59

28. Cheetham TD, Connors M, Clayton K, Watts A, Dunger DB (1997) The relationship between overnight GH levels and insulin concentrations in adolescents with insulin-dependent diabetes mellitus (IDDM) and the impact of recombinant human insulin-like growth factor I (rhIGF-I). Clin Endocrinol (Oxf) 46: 415-425

29. Rizza RA, Mandarino LJ, Gerich JE (1982) Effects of growth hormone on insulin action in man. Mechanisms of insulin resistance, impaired suppression of glucose production, and impaired stimulation of glucose utilization. Diabetes 31: 663-669

30. Bratusch-Marrain PR, Smith D, DeFronzo RA (1982) The effect of growth hormone on glucose metabolism and insulin secretion in man. J Clin Endocrinol Metab 55: 973-982

31. Randle PJ, Garland PB, Hales CN, Newsholme EA (1963) The glucose fatty-acid cycle. Its role in insulin sensitivity and the metabolic distrubances of diabetes mellitus. Lancet i:785-789

32. Bonadonna RC, Zych K, Boni C, Ferrannini E (1989) Time dependence of the interaction between lipid and glucose in humans. Am J Physiol 257:E49-E56

33. Walker M, Fulcher GR, Sum CF, Orskov H, Alberti KGMM (1991) Effecdt of glycemia and nonesterified fatty acids on forearm glucose uptake in normal humans. Am J Physiol 261:E304-E311

34. Cherrington AD, Edgerton D, Sindelar DK (1998) The direct and indirect effects of insulin on hepatic glucose production in vivo. Diabetologia 41: 987-996

35. Piatti PM, Monti LD, Caumo A et al. (1999) Mediation of the hepatic effects of growth hormone by its lipolytic activity. J Clin Endocrinol Metab 84: 1658-1663

36. Okuda Y, Pena J, Chou J, Field JB (1994) Effect of growth hormone on hepatic glucose and insulin metabolism after oral glucose in concious dogs. Am J Physiol 267:E454-E460

37. Monti LD, Brambillla P, Caumo A et al. (1997) Glucose turnover and insulin clearance after growth hormone treatment in girls with Turner's syndrome. Metabolism 46: 1482-1488

38. Widmer A, Keller U, Pasquel M, Berger W (1988) Alterations in insulin clearance and hepatic blood flow during the night do not contribute to the 'Dawn Phenomenon' in Type I diabetes. Hormone Res 29: 197-201

39. DeFeo P, Perriello G, Ventura MM et al. (1986) Studies on overnight insulin requirements and metabolic clearance rat of insulin in normal and diabetic man: relevance to the pathogenesis of the dawn phenomenon. Diabetologia 29: $475-480$

40. Brennan JR, Gebhart SSP, Blackard WG (1985) Pump-induced insulin aggregation: a problem with the Biostator. Diabetes 34: 353-359

41. Van Haeften TW, Bolli GB, Dimitriadis GD, Gottesman IS, Horwitz DL, Gerich JE (1986) Effect of insulin antibod- 
ies and their kinetic characteristics on plasma free insulin dynamics in patients with diabetes mellitus. Metabolism 35: 649-656

42. Toft I, Bonaa KH, Lindal S, Jenssen T (1998) Insulin kinetics, insulin action, and muscle morphology in lean and slightly overweight persons with impaired glucose tolerance. Metabolism 47: 848-854

43. Ciampelli M, Fulghesu AM, Cucinelli F et al.(1997) Heterogeneity in beta cell activity, hepatic insulin clearance and peripheral insulin sensitivity in women with polycystic ovary syndrome. Hum Reprod 12: 1897-1901

44. Van Haeften TW, Bolli GB, Dimitriadis GD, Gottesman IS, Horwitz DL, Gerich JE (1986) Effect of insulin antibodies and their kinetic characteristics on plasma free insulin dynamics in patients with diabetes mellitus. Metabolism 35: 649-656

45. Campbell PJ, Gerich JE (1990) Impact of obesity on insulin action in volunteers with normal glucose tolerance: Demonstration of a threshold for the adverse effect of obesity. J Clin Endocrinol Metab 70: 1114-1118

46. Macor C, Ruggeri A, Mazzonetto P, Federspil G, Cobelli C, Vettor R (1997) Visceral adipose tissue impairs insulin secretion and insulin sensitivity but not energy expenditure in obesity. Metabolism 46: 123-129

47. Mingrone G, DeGaetano A, Greco AV et al. (1997) Reversibility of insulin resistance in obese diabetic patients : role of plasma lipids. Diabetologia 40: 599-605

48. Phillips DIW, Caddy S, Ilic V et al. (1996) Intramuscular triglyceride and muscle insulin sensitivity: evidence for a relationship in nondiabetic subjects. Metabolism 45: 947-950

49. Svedberg J, Bjorntorp P, Smith U, Lonnroth P (1990) Freefatty acid inhibition of insulin binding, degradation, and action in isolated rat hepatocytes. Diabetes 39: 570-574

50. Pagano C, Rizzato M, Lombardi AM et al. (1996) Effect of lactate on hepatic insulin clearance in perfused rat liver. Am J Physiol 270:R682-R687
51. Boden G (1997) Role of fatty acids in the pathogenesis of insulin resistance and NIDDM. Diabetes 46: 3-10

52. Edge JA, Pal BR, Harris DA, Matthews DR, Phillips PE, Dunger DB (1993) Evidence for a role for insulin and growth hormone in the overnight regulation of 3-hydroxybutyrate in normal and diabetic adolescents. Diabetes Care 16: 1011-1018

53. Rizack MA (1960) Intravascular effect of heparin on plasma nonesterified fatty acid and triglyceride during alimentary lipemia. Proc Soc Exp Biol Med 104: 111-113

54. Miller DS, Sykes DB (1991) Stimulation of protein synthesis by internalised insulin. J Cell Physiol 147: 487-494

55. Seta KA, Roth RA (1997) Overexpression of insulin degradation enzyme : cellular localization and effects on insulin signaling. Biochem Biophys Res Commun 231: 167-171

56. Duckworth WC, Hamel FG, Peavy DE (1988) Hepatic metabolism of insulin. Am J Med 85: 71-76

57. Sato H, Terasaki T, Mizuguchi H, Okumura K, Tsuji A (1991) Receptor-recycling model of clearance and distribution of insulin in the perfused mouse liver. Diabetologia 34: 613-621

58. Letiexhe MR, Scheen AJ, Gerard PJ et al. (1993) Insulin secretion, clearance, and action on glucose metabolism in cirrhotic patients. J Clin Endocrinol Metab 77: 1263-1268

59. Jones CN, Pei D, Staris P, Polonsky KS, Chen YDI, Reaven GM (1997) Alterations in glucose-stimulated insulin secretory dose-response curve and insulin clearance in nondiabetic insulin resistant individuals. J Clin Endocrinol Metab 82: $1834-1838$

60. Nijs HGT, Radder JK, Frolich M, Krans HMJ (1990) In vivo relationship between insulin clearance and action in healthy subjects and IDDM patients. Diabetes 39: 333-339

61. Mosthaf L, Busch AK, Juhl LF, Nieslen L, Olsen GS, Ikeda Y, Seedorf K (1998) The insulin receptor is degraded by specific protein kinase C isoforms. Diabetologia 41 [Suppl 1]:532 